There were 8,782 tents established in $>11$ camps. Medical assistance for the people that lived in the tent camps was delivered by EKAB, in coordination with other teams such as the Red Cross, hospital medical teams, army hospital medical teams, and the medical teams provided by non-governmental organizations.

Conclusion: The lessons learned included the need to improve planning. EMS must be educated better in risk assessment, preparedness, and planning for major incidents. Keywords: Athens; buildings; conceptual framework; coordination; earthquake; emergency medical services; medical care; mortality; planning; preparedness; rescue; Task Force for Quality Control of Disaster Medicine; tents; World Association for Disaster and Emergency Medicine

Prehosp Disast Med 2005;20(2):54-55

\section{Disaster Health Education and Training: A Pilot Questionnaire to Understand Current Activities V. Murray;, ${ }^{1}$ J. Clifford, ${ }^{2}$ G. Seynaeve, J. Fisher ${ }^{4}$ \\ 1. Chemical Hazards and Poisons Division, London, United Kingdom \\ 2. United Kingdom \\ 3. Belgium \\ 4. USA}

Introduction: Following a World Association for Disaster and Emergency Medicine (WADEM) Seminar to progress Disaster Education and Training held by the Education Committee in Brussels in October, 2004, it was apparent that there was no single tool available to assess knowledge, skills, and resources within this field..$^{1,2}$ It was decided to pilot such a tool using the fifty delegates present to assess whether it would facilitate information sharing and curriculum development in disaster health education.

Methods: The WADEM Education committee had devised a reference scheme based on seven educational levels, ${ }^{1}$ within a framework based on the Bradt model. ${ }^{3}$ A questionnaire was developed, based on this scheme, to answer the following questions:

1. Was training delivered using seminars, lectures, papers or books?

2. Was it delivered face-to-face or by distance learning?

3. Was it occasional or routine?

4. Was it delivered as part of initial training or as continuing education?

5. To whom is it given and by whom?

6. What competencies are taught?

7. Is there a charge?

8. Is it accredited, either internally or externally?

9. In what language is it delivered?

The pilot was sent out to all delegates and the responses were analyzed.

Conclusions: The pilot proved to be a useful tool to share knowledge within the WADEM. It could be repeated and updated regularly (possibly annually). Wider use is recommended to evaluate current educational resources, not only in disaster medicine, but also in the wider educational field. It will facilitate the development and audit of accredited courses. ${ }^{4,5}$

References:

1. Seynaeve G, Archer F, Fisher J, et al: International standards and guidelines on education and training for the multi-disciplinary health response to major events which threaten the health status of a community. Prebosp Disast Med 2004;19(S2):s17-s30.
2. Hsu EB, Jenckes MW, Catlett CL, et al: Effectiveness of hospital staff masscasuaity incident training methods: A systematic literature review. Prehosp Disast Med 2004:19(3):191-199.

3. Bradt D, Abraham K, Franks R: A strategic plan for disaster medicine in Australasia. Emerg Med 2003;15:271-282.

4. Association of Schools of Public Health in the European Region (ASPHER) Accreditation Task Force: Accreditation framework. 11-14 September 2004. More information available at www.aspher.org.

5. The Final Report of the Blue Ribbon Task Force. 12 September 2003. Accrediting Commission on Education for Heaith Services Administration (ACEHSA) and the National Center for Healthcare leadership (NCHL) Available at www.nchl.org and www.acehsa.org.

Keywords: assessment; disaster; education; health; training; World Association for Disaster and Emergency Medicine (WADEM) Prehosp Disast Med 2005;20(2):s5

\section{National Strategy of Training Disaster Medicine Service Experts in Russia}

\section{Preobrazhenskiy}

1. All-Russian Centre for Disaster Medicine (ARCDM) "ZASCHITA", Russia

Introduction: Technogenic accidents and disasters have increased over the last three years in Russia. In this context, a greater importance is given to problems of terrorism, thus necessitating training disaster medicine service experts to reduce health after-effects of emergencies.

The top institution for training of disaster medicine experts is the Institute for Disaster Medicine Problems, located at the All-Russian Centre for Disaster Medicine "Zaschita" (ARCDM "Zaschita"), and in other regions in Russia - regional institutes for advanced medical training constitute a part of disaster medicine sub-faculties.

A primary goal of the national strategy of education involves the training of highly qualified, disaster medicine experts for minimizing emergency after-effects and the realization of the strategy of medical care delivery at prehospital and hospital stages, preparedness of medical instirutions for mass admission of the injured and patients, and timely medical care delivery.

Methods: Within the framework of the Institute for Disaster Medicine Problems, the following tasks are being solved: (1) organization and implementation of occupational training and certification of disaster medicine experts in the sphere of management, treatment and prophylaxis; (2) implementation and coordination of scientific research, relating to topical disaster medicine problems; (3) implementation of regional and inter-regional drills on basic disaster medicine problems (radiation and chemical accidents, terrorist attacks, etc.); (4) training scientific and teaching personnel for disaster medicine; and (5) development and introduction of new forms of training (modular training, telemedicine conferences, etc.).

More than 6,000 students underwent training in 20 cycles of disaster medicine professional skills during 2000-2003. Being the Euroasian training center, ARCDM "Zaschita" conducts out-training cycles in NIS-republics. Discussion: The new standardized curricula were highly praised by the Ministry of Health in Russia and recommended for higher institutions for training disaster medicine experts. The basis of the curricula is formed of modern scientific and practical developments in disaster medicine and provide new teaching aids (information and telemedi- 